\title{
Extrusion Cooking Technology: Principal Mechanism and Effect on Direct Expanded Snacks - An Overview
}

\author{
TiWARI AJITA ${ }^{a^{*}}$ AND JHA S. K. ${ }^{b}$ \\ ${ }^{a}$ Department of Agricultural Engineering, Assam University, Silchar- 788011 \\ b Division of Post Harvest Technology, Indian Agricultural Research Institute, New Delhi-110012 \\ ${ }^{*}$ Corresponding author \\ ajitatiwari@gmail.com
}

Received: 01 February 2016; Published online: 18 April 2017

\begin{abstract}
The snack industry is one of the fastest growing food sectors and is an important contributor within the global convenience food market. Nowadays snacks and convenience foods are also consumed regularly in India. Properly designed convenience foods can make an important contribution to nutrition in societies where social changes are altering traditional patterns of food preparation. Extrusion cooking as a popular means of preparing snack foods based on cereals and plant protein foodstuff has elicited considerable interest and attention over the past 30 years. Several studies on the extrusion of cereals and pulses, using various proportions, have been conducted because blends of cereals and pulses produce protein enriched products. Special importance is placed on the physicochemical and chemical modifications of protein, starch and dietary fibre. Extruded products can be categorized for a particular application based on their functional properties such as water absorption and water solubility index, expansion ratio, bulk density and viscosity of the dough.

Therefore, the literature was reviewed for effect of extrusion processing on product parameters, and nutritional and anti-nutritional properties of extruded products.
\end{abstract}

Keywords: Extrusion processing; Direct expanded snack; Single screw extruder; Twin-screw extruder

\section{Extrusion processing of food}

The extrusion process is an efficient continuous process, which uniquely combines several unit operations, viz: mixing, shearing, heating, pumping, forming, and sizing. Food extruders are classified thermally as forming or cooking, and geometrically as single or twin screws. The single screw extruder is a bioreactor which transforms a variety of raw food materials like maize, starch, wheat, rice and soy into products such as snack foods, pasta, processed meats, fillings and pet feeds. The single screw extruder consists of a precision screw rotating inside a smooth bore or grooved barrel (pipe). Single screw cooking extruders (SSCE) are used to produce dry and semi moist pet foods, expanded snacks, breakfast cereals, puddings, soup and drink bases, gelatinized starch and texturized vegetable proteins. The mechanical energy for rotation is supplied from a reduction gear and variable speed electric motor. The barrel is usually heated by electric heater bands wrapped around the barrel. There is a vertical feed hopper with volumetric screw feeder (variable speed drive is provided for this to control the flow rate of food materials) for controlling the amount of food materials entering the extruder (Fig 1). The exit end of the barrel is fitted with some sort of restriction (breaker plate) and suitably shaped die orifices through which the extruded product passes out to atmosphere. Extruders used for producing direct ex- 
panded products usually have a $\mathrm{L} / \mathrm{D}$ ratio of 10:1 or 12:1 and screw speeds in excess of $200 \mathrm{rpm}$ to provide high shear and friction energy, and short residence times for the food materials.

A direct expanded product or $2^{\text {nd }}$ generation snack food gets its name because it is formed on extrusion, and expands immediately as it emerges from the die, requiring only additional drying or frying to reduce moisture content and make ready for consumption. While a $3^{\text {rd }}$ generation snack food (pellet) is made in 2 stage extrusion, namely cooking at high shear followed by additional low shear processing or cooling to extrude out through the low shear extruder, without any expansion. The pellet needs to be fried at high temperatures for final expansion and consumption. Pasta products like vermicelli are usually processed using cold forming or low shear extruder which generates very little shear on the food materials and serves to pump the ingredients through a shaping die. Direct expanded products are usually light, which means they have a low bulk density (typically 50-160 g/l), and are coated with flavours and seasonings for additional taste and mouth feel.

A single screw extruder has a single screw rotating inside a stationery barrel and relies on frictional forces to transport the material forward for maximum throughputs. There are three types of flows associated with a single screw extruder, viz: drag flow, leakage flow and pressure flow. Drag flow is because of friction between the material and inner barrel, with the material being conveyed forwards due to the rotating action of the screw. The small amount of leakage flow tends to reduce the net output because of leakage taking place in the clearance between the screw and barrel, hence only the necessary amount of clearance is kept between the screw and barrel. The restrictor plate, consisting of breaker plate and dies, provides a restriction against which the extruder screw must pump the material. These restrictors build up the pressure inside the extruder, which is useful for better mixing of products, but results in a net loss of output from the extruder due to pressure build-up. The food materials are usually sticky while processing and tend to adhere to the rotating screw, again reducing the output available from the extruder. A single screw extruder is usually considered a poor mixer, and it is not possible to add dry or liquid components in the extruder barrel. Hence, all components are mixed in a blender prior to entry into the extruder. Direct expanded products made from wheat, rice and high potato loadings are difficult to run on a single screw extruder, with incomplete puffing a usual result. An increased L/D ratio or a twin screw extruder is needed for a good result.

Twin-screw extruder applications include most SSCE products and chocolate coatings, candies, gums and enzyme modified products (Harper \& Clark, 1979). A food extruder is a high temperature short time bioreactor that transforms a variety of raw materials/ingredients into finished product. Extrusion processing is a continuous process. The extruded products are sterile and because of complete starch gelatinization, very digestible (Seib, 1976).

Extrusion cooking technology, a high temperature short time (HTST) process, is increasingly used in the food industries for the development of new cereal based snacks, including dietary fiber, baby foods, breakfast cereals and modified starch from cereals (Sebio \& Chang, 2000; Pardeshi \& Chattopadhyay, 2014; Pawar, Pardeshi, Borkar, \& Rajput, 2014; Navale, Swami, \& Thakor, 2015). As it is a HTST process, which reduces microbial contamination and inactivates enzymes, the main method of preservation of both hot and cold extruded foods is by the low water activity of the product (0.1-0.4) (Bordoloi \& Ganguly, 2014). Extrusion cooking has been used for processing of starchy as well as proteinaceous materials for a long time. As extrusion processing is a thermally efficient process, it offers many advantages in processing soy based products. Due to high temperature short time cooking of a soy- cereal blend, the antinutritional factors are effectively destroyed without damage to nutritional quality of the raw material (Harper \& Jansen, 1981). 


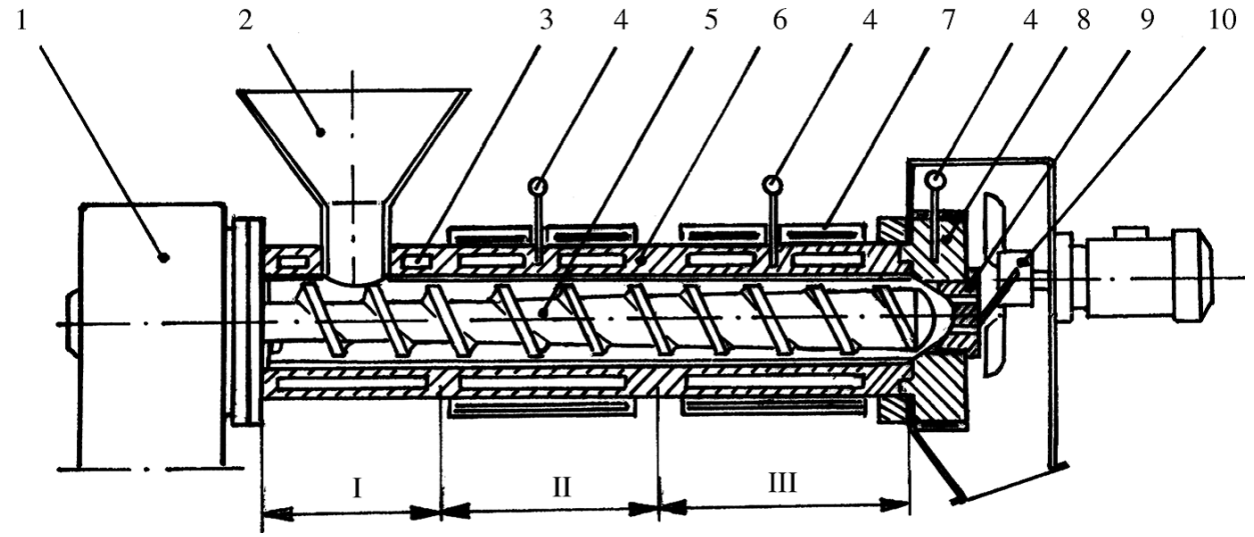

Figure 1: A cross-section of a single-screw food extruder

1 - engine, 2 - feeder, 3 - cooling jacket, 4 - thermocouple, 5 - screw, 6 - barrel, 7 - heating jacket, 8 head, 9 - dies, 10 - cutter, I - transport section, II - compression section, III -melting and plasticizing section (Moscicki, Mitrus, Wojtowicz, Oniszczuk, \& Rejak, 2013).

\section{Equipment \& Processing steps in making a direct expanded product:}

There are different processing steps involved in the production of direct expanded snacks (Fig 2).

Mixed raw material/ Blender: This usually takes the form of a ribbon blender. The mixing tool inside the vessel is in the shape of a spiral ribbon which rotates through a reduction gear and electric motor. All the dry ingredients, along with liquid ingredients such as an emulsifier, lipids, and moisture (water), are loaded in measured amounts to the blender and mixed for the required time. Since the moisture content for an expanded product is low (less than 20\%), it can be added to the blender with dry ingredients. This is a batch mixing process.

Variable speed feeder: This is usually in the form of an inclined screw conveyor, rotated by a geared motor, which transfers the pre blended raw-materials from the blender to the extruder hopper.

Extruder: The extruder has a hopper fitted with a horizontal auger screw run by a variable speed motor. The volumetric feeder constantly supplies a preset amount of raw-materials into the extruder inlet and over the extrusion screw running inside a grooved, electrically heated barrel. These materials are continuously moved through processing zones and forced through the die into the desired shape. Product temperature at the die exit can be as high as $190^{\circ} \mathrm{C}$. Use of twin screw extruders is growing rapidly in the food industry as explained earlier. The extruder has no heating provision and the product gets sheared and temperature rises because of mechanical working of the ingredients between the plates. This extruder is almost superseded by the modern high shear cooking extruder which has versatility and immense product possibilities.

Cutters/ knife: Automatic cutters are of a dieface cut variety and usually consist of a set of rotating knifes through a variable speed motor. Three dimensional cutting blades are more sophisticated and need additional knives, mounted at proper angles, to form three dimensional cut figures.

Dryer: Continuous running steel perforated belts, arranged for single or multiple passes, 


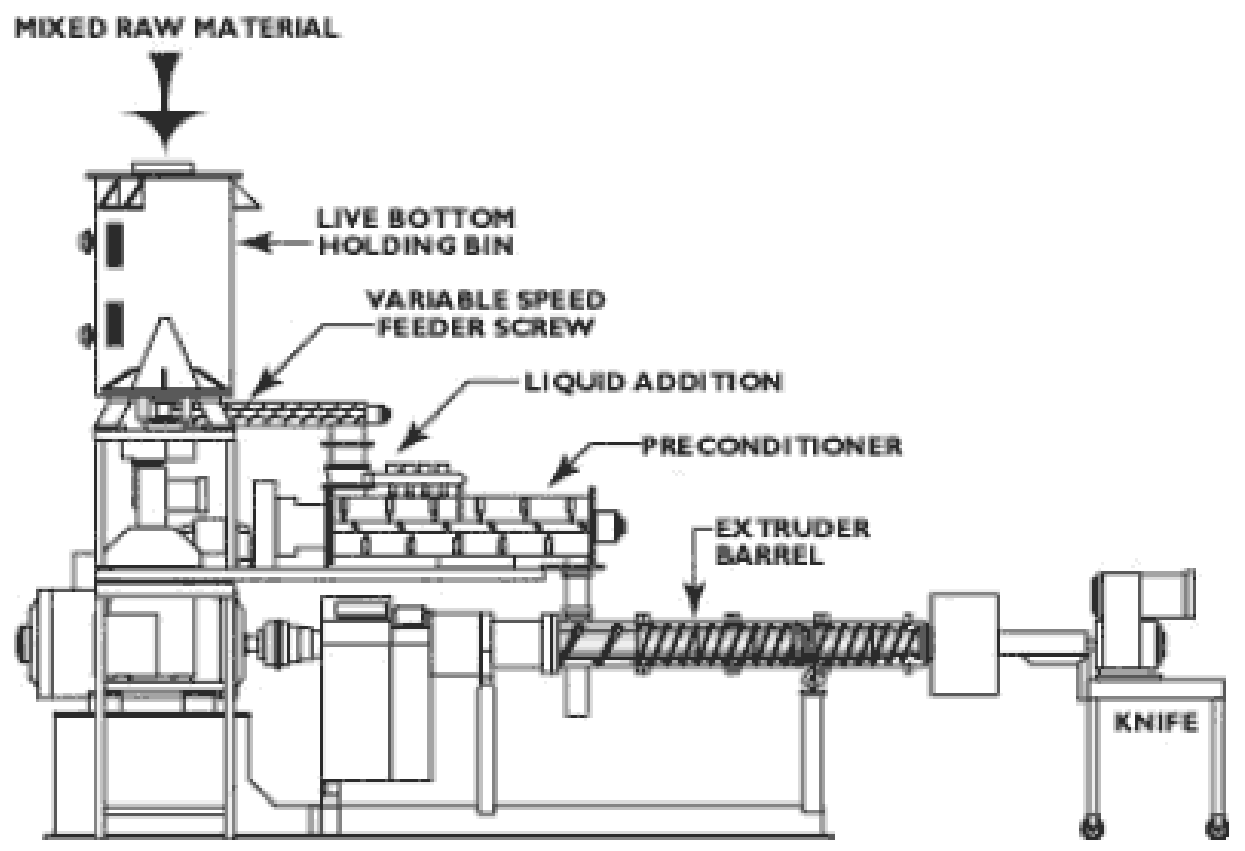

Figure 2: Layout of a typical Snack Food line for Direct expanded products

dry the extruded product down to $1-1.5 \%$ moisture content (wet basis). The dryer is used to produce baked collet and other products of low bulk density, whilst an additional fryer is required to produce high density products. For example, corn curls produced on a collet extruder are usually fried in a fryer to reduce the moisture level.

Coating unit: A coating unit is used to spray oil on an expanded product and to dust product with a suitable seasoning such as salt for additional mouth feel and crunch. In some units, the dryer and coating units are combined.

\section{$3 \quad$ Effect of extrusion processing on product parameters}

Extrusion cooking/processing of blended foods requires consideration of characteristics of starcheous and proteinaceous material that is gelatinization of starch and denaturation of proteinaceous material to produce quality extruded products (Mercier, Linko, \& Harper, 1989). Research carried out by different workers on the effect of processing parameters on extruded snack food quality is presented below.

\subsection{Expansion}

The expansion was characterized on cooled and dimensionally stable products. Expansion parameters were derived both from bubble growth to maximum size and from the ensuing contraction (DellaValle, Colonna, Patria, \& Vergnes, 1996). In a food extrusion cooking process, the product (extrudate) expansion is a fundamentally important property, describing the product quality, and is directly related to the degree of cooking. Unless the extrudate expansion meets a certain specification, the product is not acceptable. Thus, understanding of the effects of process parameters on extrudate expansion become crucial in the extrusion cooking process. Many theories and models have been 
Extrusion cooking technology: principle mechanism and effects $\mid 117$

proposed to describe the extrudate expansion for several raw materials (Alvarez-Martinez, Kondury, \& Harper, 1988; Moraru \& Kokini, 2003). Some researchers use empirical regressions of process operation parameters and raw material compositions to explain the extrudate expansion (Chevanan, Muthukumarappan, Rosentrater, \& Julson, 2007, 2007, 2008; Shukla, Muthukumarappan, \& Julson, 2005). Faubion and Hoseney (1982-b) reported that the expanded volume of feed decreased with increasing amounts of proteins in the feed material, but increased with increasing starch content. In order to account for extrudate expansion on removal from the die, longitudinal (LEI) and sectional expansion indices (SEI) proposed by Alvarez-Martinez et al. (1988) were calculated. For corn extrudates, no significant change in SEI occurred between 200 and $300 \mathrm{rpm}$, however, a significant drop (39\%) below the initial SEI was recorded for a speed of $500 \mathrm{rpm}$. Otherwise, the increase in screw speed induced a significant rise in the longitudinal expansion of extrudates for the two types of flour. The LEI for wheat and corn extrudates displayed an overall increase of $43 \%$ and $46 \%$, respectively, for an increase in speed from 200 to $500 \mathrm{rpm}$. The lowest screw speed (200 rpm) generated a product featuring greater sectional expansion for corn flour than for wheat flour, however, at the highest screw speed (500 rpm) this trend was reversed when a sharp decrease in sectional expansion index was seen for corn extrudates. Longitudinal expansion seemed to be independent of flour type. The higher screw speed induced a decrease of sectional expansion along with an increase in longitudinal expansion, yet corn-based products proved to be more sensitive to sectional expansion than wheat based products. Onwulata, Smith, Konstance, and Holsinger (2001) studied the effect of incorporation of whey protein at $0,25 \%$ and $50 \%$ in extruded corn, potato and rice snacks. At high shear rate the expansion indexes (EI) were found to be 2.4, 1.5 and 1.3 respectively with corn flour extrudate, 2.2 , 1.8 and 1.6 respectively with potato flour extrudate, and 2.8, 2.6 and 1.8 respectively with rice extrudate. Similarly Ozer, Herken, Guzel, Ainsworth, and Ibanoglu (2006) reported that screw speed and feed moisture in a nutrition blend (Chickpea, corn, Oat, Corn starch, Car- rot powder and Ground raw hazelnut) had significant effects on radial and axial expansion, which were in the range of 2.36 to 3.08. Faubion and Hoseney (1982-a) found that expansion was greater for starch than wheat extrudates, and decreased with increasing moisture. According to Kannadhason, Muthukumarappan, and Rosentrater (2009), the expansion ratio of cassava and potato starch was found to decrease by $12.3 \%$ and $10.6 \%$, respectively, with a change in net protein content from $28 \%$ and $32 \%$ wt.. At higher moisture content, the expansion showed a maximum with respect to temperature, as reported for maize (Mercier, 1979) and manioc starch (Mercier, 1980). Moraru and Kokini (2003) reported that the attempt to incorporate high levels of fiber in extruded products often resulted in a compact, tough, non-crisp and undesirable texture in extrudates, and also reduced expansion. Falcone and Phillips (1988) studied sorghum and cowpea blends and found that both temperature $\left(175-205^{\circ} \mathrm{C}\right)$ and moisture $(20.5-25 \%)$ had negative effects on expansion for most compositions. Various studies on extrusion of proteinaceous (Lawton, Davis, \& Behnke, 1985) and starchy (Gomez \& Aguilera, 1984) systems have found that puffing is directly related to temperature and inversely related to moisture. They observed that adding protein to a starchy extrusion system may interfere with expansion, and also that amylopectin exerts a positive and amylose a negative influence on expansion. Altan, McCarthy, and Maskan (2008) studied the effect of die temperature $\left(140-160^{\circ} \mathrm{C}\right)$, screw speed $(150-200 \mathrm{rpm})$ and pomace level (2-10\%) on barley-grape pomace extrudate and found that temperature had more effect. EI decreased with increasing barrel temperature and the value ranged between 0.949 and 1.747. Ding, Ainsworth, Tucker, and Marson (2005) studied the effects of extrusion conditions on physicochemical properties of rice based snacks, and feed moisture was found to be the main factor affecting the extrudate expansion. The highest expansion (3.87) was reported at $14 \%$ feed moisture, $120^{\circ} \mathrm{C}$ barrel temperature and screw speed at $250 \mathrm{rpm}$.

The expansion ratio increases with decrease in feed moisture content and increase in screw speed and barrel temperature. Increased feed moisture leads to a sharp decrease in the expansion 
of extrudate (Pathania, Singh, Sharma, Sharma, \& Singla, 2013). Oke, Awonorin, and Workneh (2013) reported that changing the feed moisture content, barrel temperature and screw speed significantly affected the expansion ratio of all the extrudates. Increasing the feed moisture content and screw speed resulted in a substantial decrease in expansion ratio.

\subsection{Bulk Density}

The extrudate density was found to be most dependent on feed moisture. Screw speed and temperature also have significant effects on the density of extrudate. Increased feed moisture leads to a sharp increase in extrudate density. However, increased screw speed and barrel temperature caused a slight decrease in the density of extrudate. Ding et al. (2005) studied the effect of extrusion conditions on physicochemical properties of rice based snacks, and feed moisture was found to be main factor affecting the extrudate expansion. The lowest bulk density $\left(0.1 \mathrm{~g} / \mathrm{cm}^{3}\right)$ was reported at lowest feed moisture (14\%) and highest barrel temperature $\left(140^{\circ} \mathrm{C}\right)$.

Altan et al. (2008) studied the effect of die temperature $\left(140-160^{\circ} \mathrm{C}\right)$, screw speed $(150-200 \mathrm{rpm})$ and pomace level $(2-10 \%)$ on barley- grape pomace extrudate and found that both (pomace level and barrel temperature) had significant effect on bulk density. The bulk density of extrudates was in the range 0.325 to $1.18 \mathrm{~g} / \mathrm{cm}^{3}$. An increase in temperature from 140 to $150^{\circ} \mathrm{C}$ decreased the bulk density from 0.85 to $0.25 \mathrm{~g} / \mathrm{cm}^{3}$, whereas, an increase in pomace level increased the bulk density from 0.325 to $.95 \mathrm{~g} / \mathrm{cm}^{3}$. The highest $\mathrm{BD} 1.18 \mathrm{~g} / \mathrm{cm}^{3}$ was found at $140^{\circ} \mathrm{C}$ and $10 \%$ pomace.

Feed moisture has been found to be the main factor affecting extrudate density and expansion (Faubion \& Hoseney, 1982-a; Fletcher, Richmond, \& Smith, 1985; Ilo, Liu, \& Berghofer, 1999; Launay \& Lisch, 1983). The high dependence of bulk density and expansion on feed moisture reflects its influence on elasticity characteristics of the starch-based material. Increased feed moisture content during extrusion may reduce the elasticity of the dough through plasticization of the melt, resulting in reduced
SME and therefore reduced gelatinization, decreasing the expansion and increasing the density of extrudate.

It was observed that an increase in screw speed resulted in an extrudate with lower density.

Higher screw speeds may be expected to lower the melt viscosity of the mix, increasing the elasticity of the dough, resulting in a reduction in the density of the extrudate. This effect has been reported previously (Fletcher et al., 1985). An increase in the barrel temperature will increase the degree of superheating of water in the extruder, encouraging bubble formation and also a decrease in melt viscosity (Fletcher et al., 1985), leading to reduced density. Similar results have been observed by Mercier and Feillet (1975). The bulk density of extrudate increased with decreasing expansion ratio. Expansion and bulk density are also related to starch gelatinization (Case, Hamann, \& Schwartz, 1992). According to these authors, an increase in gelatinization increased expansion and decreased bulk density.

The effects of the independent variables (temperature, screw speed and moisture content) on density of extrudates were opposite to that of their effects on expansion ratio (Pathania et al., 2013). Increasing barrel temperature and screw speed resulted in lower bulk densities of extrudates, whilst increasing the level of moisture resulted in the minimum bulk density (Kothakota, Jindal, \& Thimmaiah, 2013). Phillips and Falcone (1988) investigated the effects of barrel temperature $\left(160\right.$ and $\left.205^{\circ} \mathrm{C}\right)$ and feed moisture content (13-25\%) on the physical and rheological properties of extrudates prepared from mixtures of sorghum and full-fat peanut meals, using a single screw extruder. They found that the maximum expansion was obtained at a low to medium temperature and moisture content.

\subsection{Water Absorption Index (WAI) and Water Solubility Index (WSI)}

The WAI measures the amount of water absorbed by starch and can be used as an index of starch gelatinization (Anderson, Conway, Pfeifer, \& Griffin, 1969; Ding et al., 2005, 2006). WSI, often used as an indicator of degradation 
Extrusion cooking technology: principle mechanism and effects 119

of molecular components (Kirby, Ollett, Parker, \& Smith, 1988), measures the amount of soluble components released from the starch after extrusion. When mixed with water, extruded products will often swell and a portion of this material will become soluble. Water solubility and absorption parameters characterize the extruded product and are often important in predicting how the extruded material may behave if further processed.

Water absorption index indicates the amount of water immobilized by the extrudate, while water solubility indicates the amount of small molecules solubilised in water. An increase in barrel temperature resulted in higher WAI (Kothakota et al., 2013). Increased feed moisture content and screw speed significantly increased the WAI of texturized rice whereas an increase in barrel temperature was observed to cause a significant decrease in texturized rice. Anderson et al. (1969) recorded a method to estimate the amount of material that can be extracted by water from an extruded product. The materials which are soluble include gelatinized starch, undenatured globular proteins, inorganic ions and small sugars. The WSI increased significantly when screw speed increased from 200 to $300 \mathrm{rpm}$ for wheat extrudates and from 300 to $500 \mathrm{rpm}$ for corn extrudates (Mezreb, Goullieux, Ralainirina, \& Queneudec, 2003). The WSI is indeed related to the degree of starch transformation. The unprocessed flours exhibited lower values of WSI than those of final products (for corn flours). Consequently, the WSI increased because starch granules were more soluble in water (Smith, 1992).

WAI increased with extrusion temperature and feed moisture content for corn and corn-lentil extrudates (Lazou \& Krokida, 2010). The WAI measures the amount of water absorbed by starch and can be used as an index of gelatinization, since native starch does not absorb water at room temperature (Colonna, Tayeb, \& Mercier, 1989; Ding et al., 2006). Extrusion temperature and moisture content are known to affect gelatinization during extrusion, and consequently the WAI. In a high moisture soy meat analog, WAI increased with increase in extrusion temperature and feed moisture (Lin, Huff, \& Hsieh, 2000). Similar results were reported for corn starch extrudates, and bean and chickpea extrudates (Singh, Sekhon, \& Singh, 2007). Also a study by Badrie and Mellowes (1991) showed that there was an increase in WAI and decrease in WSI with increasing moisture content or screw speed.

Findings by Lazou and Krokida (2010) indicated that WSI of the extrudates was significantly $(\mathrm{p}<0.001)$ affected by material ratio (legume/corn), feed moisture content, extrusion temperature and feed rate. WSI decreased with increasing feed moisture content but increasing temperature had an inverse effect. The WSI is related to the quantity of soluble molecules, which is related to dextrinization. In other words, WSI can be used as an indicator for the degradation of molecular compounds and measures the degree of starch conversion during extrusion (Colonna et al., 1989; Ding et al., 2005). The rise in temperature increases the severity of thermal treatment in the extruder, which consequently raises WSI. These observations are similar for starch-based extrudates obtained either using single or twin screw extrusion (Colonna et al., 1989; Ding et al., 2006; Kadan, Bryant, \& Pepperman, 2003; Pathania et al., 2013).

Furthermore, dextrinization is well known as the predominant mechanism of starch degradation during low moisture extrusion. Therefore, the decreasing trend of WSI with feed moisture content is expected and in agreement with previous reports (Ding et al., 2005; HernandezDiaz, Quintero-Ramos, Barnard, \& BalandranQuintana, 2007).

\subsection{Product moisture}

Product moisture was found to be directly related to feed moisture and inversely related to extrusion temperature (Maurice \& Stanley, 1978; Phillips \& Falcone, 1988). The moisture content of starch-PDPF extrudates, after drying at $60^{\circ} \mathrm{C}$ for $12 \mathrm{~h}$, was $4.0 \pm 0.5 \%$. The low moisture content would be anticipated to yield products with a high degree of crispness. Water activity of extrudates after drying ranged from 0.1 to 0.33 . The low water activity value ( 0.1 to 0.33 ) would be advantageous with regards to the stability of the extrudate against microbial growth. 
Product quality attributes such as expansion and degree of cooking as inferred from absorption and solubility indices are directly correlated with moisture (Kirby et al., 1988). Moisture, solubility indices and breaking strength were significantly correlated $\left(\mathrm{R}^{2}=0.92\right)$ for $100 \%$ corn but not with either substituted whey product. Moisture within the extruder acted as a heat sink thereby reducing the melt temperature. As the melt temperature decreased, the product became less viscous, and pressure was increased. Increasing shear rate, by changing to high shear extrusion, reduced the effects of moisture but led to considerable instability. Similarly puffed products with high moisture content tended to have thicker cell walls and were harder (Mercier, 1979).

Water-holding capacity and expansion of extruded products is affected by moisture (Bhattacharya \& Hanna, 1987). It is necessary to adjust the water content carefully to result in expansion with whey incorporated products. The increased structural binding of water may have reduced the moisture available for flash-off and consequently reduced expansion.

\subsection{Specific mechanical energy (SME)}

The specific mechanical energy (SME) is responsible for fragmentation of starch molecules (Gomez \& Aguilera, 1983, 1984; van Lengerich, 1990; Politz, Timpa, \& Wasserman, 1994). As a result of the applied shear forces, amylopectin molecules are broken mainly at the $\alpha-1$ :6 bonds. This phenomenon was attributed to a decrease in viscosity, with an increase in water content that decreased the shear forces applied to the molecules (Gomez \& Aguilera, 1983, 1984). The degradation products are macromolecules in the range of 50,000-200,000 MW. Limits of 105 to 107 MW for the fragments were also reported by van Lengerich (1990) and Politz et al. (1994). According to van Lengerich (1990), after maximum depolymerization of amylopectin occurs during extrusion cooking, no significant further molecular degradation of starch takes place. These studies also showed that over the water content ranges of $20-30 \%$, the higher the wa- ter content, the lesser the degradation. In contrast to these observations on starch degradation, Wen, Rodis, and Wasserman (1990) found that corn proteins were more resistant to shear forces and did not fragment during extrusion.

Kaletunc and Breslauer (1993) used the model of starch fragmentation to explain their results that showed a decrease in the glass transition temperature $(T \mathrm{~g})$ with an increase of SME. Mitrus (2005) reported that lowest SME values were obtained for potato starch extrusion, whereas the highest were for wheat starch processing. It was also detected that there are differences in SME values for potato starch, with varied amylose content. Specific mechanical energy changes with extrusion repetition. The higher the number of extrusion repetition, for the same material, the lower was the SME recorded (van Lengerich, 1990).

An additional effect of SME on starch is the gelatinization process that takes place during extrusion (Gomez \& Aguilera, 1983, 1984; van Lengerich, 1990). The degree of gelatinization increases with the higher value of SME. In contrast to the effect of water on macromolecule fragmentation, gelatinization of starch is more intense at higher water content.

Mercier et al. (1989) reported that SME input also depends on the exact composition of the product being extruded and increases with starch content. A general result is that SME increases when water content decreases in both single screw and twin screw extruders (Harper \& Clark, 1979; van Zuilichem, van Roekel, Stolp, \& van't Riet, 1990; Bhattacharya \& Hanna, 1987).

\subsection{Effect of extrusion on nutritional constituents}

\section{Proteins}

Proteins are a group of highly complex organic compounds that are made up of a sequence of amino acids. Protein nutritional value is dependent on the quantity, digestibility and availability of essential amino acids (Singh et al., 2007).

Several changes occur during extrusion of which denaturation is undoubtedly the most important. Extrusion may improve protein digestibility by 
Extrusion cooking technology: principle mechanism and effects $\mid 121$

denaturating proteins and exposing enzymeaccessible sites (Colonna et al., 1989). Enzymes and enzyme inhibitors generally lose activity due to denaturation. Protein digestibility value is higher for non-extruded products. The possible cause might be the denaturation of proteins and inactivation of anti-nutritional factors that impair digestion. The effects of extrusion on protein nutrition have been studied extensively for animal feeds and for human weaning foods. Total protein changes very little during most extrusion operations. Changes in nutritional quality may be overlooked if only total nitrogen is assayed. Animal feeding studies or in vitro protein digestibility testing should be performed on products that are designed to provide significant amounts of high-quality protein (Areas, 1992). Maillard reactions occur during extrusion particularly at high barrel temperature, low moisture, and high shear. All processing variables have different effects on protein digestibility. High shear extrusion conditions in particular promote denaturation (DellaValle et al., 1996), although mass temperature and moisture are also important factors. In a model system of wheat starch, glucose and lysine, low $\mathrm{pH}$ favours Millard reactions, as measured by increased colour (Bates, Ames, \& Macdougall, 1994).

Health effects of food proteins could be significantly affected by extrusion cooking if lysine is selectively lost via Millard reactions. Extrusiontexturised soy isolate fed to rats had similar effects as non-extruded soy on serum cholesterol, cholesterol and steroid fecal excretion, or protein nutrition (Fukui, Aoyama, Hashimoto, \& Yamamoto, 1993). In another rat study, amino acid-supplemented extruded pea (Pisum sativum L., cv. Ballet) seed meal and supplemented raw seeds lowered total and LDL cholesterol when compared with a control diet (Alonso, Rubio, Muzquiz, \& Marzo, 2001). The peas were extruded under fairly mild conditions $\left(145^{\circ} \mathrm{C}\right.$ exit temperature and feed moisture of $25 \%$ ), but antinutritional factors were adequately inactivated, as evidenced by lower pancreatic weights in rats fed the extruded peas.

Cooking extruders for processing high-protein materials into palatable foods is very common today. Many new applications have been developed for protein extrusion during the past decade. Im- provements in functional characteristics of proteins may be achieved through modification of temperature, screw speed, moisture content, and other extrusion parameters.

\section{Vitamins}

Daily vitamin intakes might be small compared with other nutrients but the small quantities consumed are crucial to good health because of the role vitamins play as coenzymes in metabolism. The increase in the consumption of extruded infant foods and similar products, which may form the basis of an individual's diet, has focussed concern on the effects of extrusion on the recovery of vitamins and minerals that are added prior to extrusion.

As vitamins differ greatly in chemical structure and composition, their stability during extrusion is also variable. The extent of degradation depends on various parameters during food processing and storage, for example moisture, temperature, light, oxygen, time and $\mathrm{pH}$ (Bjorck \& Asp, 1983; Camire, 1998). Minimising temperature and shear within the extruder protects most vitamins. Among the lipid-soluble vitamins, vitamins $\mathrm{D}$ and $\mathrm{K}$ are fairly stable. Vitamins $\mathrm{A}$ and $\mathrm{E}$ and their related compounds carotenoids and tocopherols, respectively, are not stable in the presence of oxygen and heat. Thermal degradation appears to be the major factor contributing to $\beta$-carotene losses during extrusion. Higher barrel temperatures $\left(200^{\circ} \mathrm{C}\right.$ compared with $125^{\circ} \mathrm{C}$ ) reduce all trans- $\beta$-carotene in wheat flour by over $50 \%$ (Guzmantello \& Cheftel, 1990).

Pham and Del Rosario (1986) and Guzmantello and Cheftel (1987) began to assess the effects of high temperature, short-time extrusion cooking on vitamin stability using mathematical models. Thiamine has been investigated most frequently, followed by riboflavin, ascorbic acid and vitamin A.

Ascorbic acid (vitamin C) is also sensitive to heat and oxidation. This vitamin decreased in wheat flour when extruded at a higher barrel temperature and fairly low (10\%) moisture (Andersson \& Hedlund, 1990). Blueberry concentrate appeared to protect $1 \%$ added vitamin $\mathrm{C}$ in an extruded breakfast cereal compared with a prod- 
uct containing just corn, sucrose and ascorbic acid. When ascorbic acid was added to cassava starch to increase starch conversion, retention of over $50 \%$ occurred at levels of $0.4-1.0 \%$ addition (Sriburi \& Hill, 2000).

The retention of vitamins in extrusion cooking decreases with increasing temperature, screw speed and specific energy input. It also decreases with decreasing moisture, feed rate and die diameter. Depending on the vitamin concerned, considerable degradation can occur, especially in products with high sensory appeal.

\section{Iron and zinc}

Mineral content and bioavailability are generally retained well during extrusion. Abrasive food (brans rich in dietary fiber or with low lipid and moisture content) gradually wear away metal from the extruder screws and barrel. The equipment must be replaced or refurbished periodically due to this wear, as the metal accumulates in the extruded food. As barrel temperature increased during single screw extrusion of potato flakes, iron content also increased (Maga \& Sizer, 1978). Total iron increased by as much as $38 \%$ due to extrusion (Camire, Zhao, \& Violette, 1993)). On the other hand, cornmeal, which has low dietary fiber content, had no changes in total, elemental, or soluble iron after twin screw extrusion (Camire, 1998).

Although iron from screw wear is typically in the elemental form, the bioavailability appears adequate as long as excessive amounts of iron and related metals are not present. Rats fed extruded corn and potato absorbed iron well (Fairweathertait, Portwood, Symss, Eagles, \& Minski, 1989). Utilisation of iron and zinc from wheat bran and wheat in adult human volunteers was not affected by extrusion (Fairweathertait et al., 1989). Lowshear extrusion retained dialysable iron in navy beans, lentils, chickpeas and cowpeas better than did high-shear extrusion (Ummadi, Chenoweth, \& Uebersax, 1995). Weaning food blends of pearl millet, cowpea and peanut had greater iron availability and protein digestibility compared to similar foods processed by roasting (Cisse et al., 1998).

Extrusion reduced phytate levels in wheat flour (Fairweathertait et al., 1989), possibly due to inactivation of phytases during extrusion. Although phytic acid was reduced under all processing conditions, total phytate was not affected. Legume phytate was not affected by extrusion (Ummadi et al., 1995).

\subsection{Antinutrient factors}

\section{Antinutrients}

Extrusion cooking also improves the nutritional quality of foods by destroying many natural toxins and antinutrients (Table 1). A dilemma exists as to whether it is desirable to remove these compounds. Enzyme inhibitors, hormonelike compounds, saponins and other compounds could impair growth and development in children, but these same compounds may offer protection against chronic diseases in adults.

\section{Phenolic compounds}

Phenolic compounds, such as genistein and phytoestrogens in soy may help prevent breast cancer, yet extrusion texturisation of soy to produce more palatable soy foods might significantly reduce these compounds (Camire, 1998). Extrusion of soy protein concentrate and a mixture of cornmeal and soy protein concentrate (80:20) did not result in changes in total isoflavone content (Mahungu et al., 1999). The aglycones and malonyl forms tended to decrease with extrusion, while acetyl derivatives increased.

Phenolic compounds in plants protect against oxidation, disease and predation. These compounds, including the large flavonoid family, are the focus of numerous studies to elucidate their role in human health. Total free phenolics, primarily chlorogenic acid, decreased significantly, owing to extrusion in potato peels produced by steam peeling (Camire, 1998). More phenolics were retained with higher barrel temperature and feed moisture. It might be possible that lost phenolics reacted with themselves or with other compounds to form larger insoluble materials. The total antioxidant activity value of samples decreased with an increase in screw speed and decrease in moisture content, while total phenolic values had insignificant (95\% confidence interval) changes after extrusion. In a model breakfast 
Extrusion cooking technology: principle mechanism and effects $\mid 123$

Table 1: Antinutrients and toxins affected by extrusion cooking

\begin{tabular}{lll}
\hline Compound & Foods & Factors favouring reduction \\
\hline Allergens & Peanuts, Soy & Increased Shear; Added Starch \\
Glucosinolates & Canola & Added ammonia \\
Glycoalkaloids & Potato & Added thiamine \\
Gossypol & Cottonseed & Higher feed moisture \\
Mycotoxins & Grains & Increased mixing, lower temperatures; added amine sources \\
Protease inhibitors & Legumes, Potato & Higher extrusion temperature \\
\hline
\end{tabular}

cereal, containing cornmeal and sucrose, anthocyanin pigments were degraded at higher levels of added ascorbic acid, and total anthocyanins significantly decreased by extrusion (Camire, 2000). Many opportunities exist for product development research in extrusion. Although several studies have been conducted on determining the effect of raw material combination and process parameters on physicochemical characteristics of direct expanded snacks as well as their storage studies. Very little has been published on the effects of extrusion on phytochemicals and other healthful food components, in part due to the need for identification of active principles and suitable analytical procedures. Evaluations of nutrient retention by either high-moisture extrusion or by supercritical fluid extrusion have yet to be published. Improved understanding of scaleup issues in extrusion is necessary for valid interpretation of studies conducted using laboratoryscale and pilot plant extruders. Long-term animal and feeding studies are tedious and costly, yet essential for demonstrating safety and efficacy of extruded foods.

\section{Conclusions}

Extrusion cooking is one of the most important food processing technologies used for the production of breakfast cereals, ready to eat snack foods and other textured foods. Nowadays extrusion cooking is a widely used technology in the agri-food processing industry. It is a popular unit operation for producing a variety of food products with numerous ingredients requiring a wide range of processing conditions and includes starch, protein, lipids, water and additives. There are ambiguous effects of extrusion cooking on nutritional quality of expanded snacks. Because of its beneficial effects such as destruction of antinutritional factors, increased soluble dietary fibres, reduction of lipid oxidation and contaminating microorganisms, it plays an important role in the production of a wide variety of foods and ingredients. As a complex multivariate process, extrusion cooking requires careful control if product quality is to be maintained. Mild extrusion conditions (high moisture content, low residence time, low temperature) favour higher retention of amino acids, high protein and starch digestibility, increased soluble dietary fibre, decreased lipid oxidation, higher retention of vitamins and higher absorption of minerals. Severe extrusion conditions and improper formulation (for example presence of reducing sugars) can cause nutritional destruction given the usual residence time of $0.5-1 \mathrm{~min}$ in the hotscrew segments. Generally, high extrusion temperature $\left(\geq 200^{\circ} \mathrm{C}\right)$ and low moisture content $(\leq$ $15 \%)$ should be avoided to maintain nutritional quality. There are many areas that require further research regarding extrusion and nutrition. Future research may be focussed on the relationships between compositional changes on product quality - both nutritional and sensory aspects, and the effects of interactions between complex extruder conditions on nutrient retention.

\section{References}

Alonso, R., Rubio, L. A., Muzquiz, M., \& Marzo, F. (2001). The effect of extrusion cook- 
ing on mineral bioavailability in pea and kidney bean seed meals. Animal Feed Science and Technology, 94(1-2), 1-13. doi:10. 1016/S0377-8401(01)00302-9

Altan, A., McCarthy, K. L., \& Maskan, M. (2008). Evaluation of snack foods from barley-tomato pomace blends by extrusion processing. Journal of Food Engineering, 84 (2), 231-242. doi:10.1016/j.jfoodeng. 2007.05.014

Alvarez-Martinez, L., Kondury, K. P., \& Harper, J. M. (1988). A general-model for expansion of extruded products. Journal of Food Science, 53(2), 609-615. doi:10.1111/j . 1365-2621.1988.tb07768.x

Anderson, R. A., Conway, H. F., Pfeifer, V. F., \& Griffin, E. L. (1969). Roll and extrusioncooking of grain sorghum grits. Cereal Science Today, 14(11), 372-\&.

Andersson, Y. \& Hedlund, B. (1990). Extruded wheat flour: correlation between processing and product quality parameters. Food Quality and Preference, 2(4), 201-216. doi:10.1016/0950-3293(90)90012-J

Areas, J. A. G. (1992). Extrusion of food proteins. Critical Reviews in Food Science and Nutrition, 32(4), 365-392.

Badrie, N. \& Mellowes, W. A. (1991). Texture and microstructure of cassava (manihotesculenta crantz) flour extrudate. Journal of Food Science, 56(5), 1319-\&. doi:10 . 1111/j.1365-2621.1991.tb04762.x

Bates, L., Ames, J. M., \& Macdougall, D. B. (1994). The use of a reaction cell to model the development and control of color in extrusion-cooked foods. Food Science and Technology-lebensmittelwissenschaft \& Technologie, 27(4), 375379.

Bhattacharya, M. \& Hanna, M. (1987). Influence of process and product variables on extrusion energy and pressure requirements. Journal of Food Engineering, 6(2), 153163. doi:10.1016/0260-8774(87)90037-9

Bjorck, I. \& Asp, N. G. (1983). The effects of extrusion cooking on nutritional value, a literature review. Journal of Food Engineering, 2(4), 281-308. doi:10.1016/0260-8774(83) 90016-X
Bordoloi, R. \& Ganguly, S. (2014). Extrusion technique in food processing and a review on its various technological parameters. Indian Journal of Scientific Research and Technology, 2(1), 1-3.

Camire, M. E. (2000). Bilberries and blueberries as functional. Herbs, Botanicals and Teas, 289-319.

Camire, M. E., Zhao, J. X., \& Violette, D. A. (1993). In-vitro binding of bile-acids by extruded potato peels. Journal of Agricultural and Food Chemistry, 41(12), 23912394. doi:10.1021/jf00036a033

Camire, M. (1998). Chemical changes during extrusion cooking - Recent advances. In Shahidi, F and Ho, CT and vanChuyen, N (Ed.), Process-induced chemical changes in food (Vol. 434, 109-121). ADVANCES IN EXPERIMENTAL MEDICINE AND BIOLOGY. Pacifichem 1995 Conference, HONOLULU, HAWAII, DEC 17-22, 1995.

Case, S. E., Hamann, D. D., \& Schwartz, S. J. (1992). Effect of starch gelatinization on physical-properties of extruded wheat-based and corn-based products. $\mathrm{Ce}$ real Chemistry, 69(4), 401-404.

Chevanan, N., Muthukumarappan, K., Rosentrater, K. A., \& Julson, J. L. (2007). Effect of die dimensions on extrusion processing parameters and properties of DDGSbased aquaculture feeds. Cereal Chemistry, 84 (4), 389-398. doi:10.1094/CCHEM-844-0389

Chevanan, N., Rosentrater, K. A., \& Muthukumarappan, K. (2007). Twin-screw extrusion processing of feed blends containing distillers dried grains with solubles (ddgs). Cereal Chemistry, 84(5), 428-436. doi:10. 1094/CCHEM-84-5-0428

Chevanan, N., Rosentrater, K. A., \& Muthukumarappan, K. (2008). Effect of ddgs, moisture content, and screw speed on physical properties of extrudates in single-screw extrusion. Cereal Chemistry, 85(2), 132-139.

Cisse, D., Guiro, A., Diaham, B., Souane, M., Doumbouya, N., \& Wade, S. (1998). Effect of food processing on iron availability of African pearl millet weaning foods. International Journal of Food Sciences and 
Extrusion cooking technology: principle mechanism and effects |125

Nutrition, 49(5), 375-381. doi:10 . 3109/ 09637489809089412

Colonna, P., Tayeb, J., \& Mercier, C. (1989). Extrusion cooking. In C. Mercier, P. Linko, \& J. M. Harper (Eds.), (Chap. Extrusion cooking of starch and starchy products, pp. 247-320). AACC - American Association of Cereal Chemists, Saint Paul. Retrieved from http: / / prodinra.inra.fr / record $/ 88865$

DellaValle, G., Colonna, P., Patria, A., \& Vergnes, B. (1996). Influence of amylose content on the viscous behavior of low hydrated molten starches. Journal of Rheology, 40(3), 347-362. doi:10.1122/1.550747

Ding, Q., Ainsworth, P., Plunkett, A., Tucker, G., \& Marson, H. (2006). The effect of extrusion conditions on the functional and physical properties of wheat-based expanded snacks. Journal of Food Engineering, 73(2), 142-148. doi:10.1016/j . jfoodeng.2005.01.013

Ding, Q., Ainsworth, P., Tucker, G., \& Marson, H. (2005). The effect of extrusion conditions on the physicochemical properties and sensory characteristics of rice-based expanded snacks. Journal of Food Engineering, 66(3), 283-289. doi:10.1016/j . jfoodeng.2004.03.019

Fairweathertait, S. J., Portwood, D. E., Symss, L. L., Eagles, J., \& Minski, M. J. (1989). Iron and zinc-absorption in humansubjects from a mixed meal of extruded and nonextruded wheat bran and flour. American Journal of Clinical Nutrition, 49(1), 151-155.

Falcone, R. G. \& Phillips, R. D. (1988). Effects of feed composition, feed moisture, and barrel temperature on the physical and rheological properties of snack-like products prepared from cowpea and sorghum flours by extrusion. Journal of Food Science, 53(5), 1464-1469. doi:10.1111/j.1365-2621.1988. tb09300.x

Faubion, J. M. \& Hoseney, R. C. (1982-a). Hightemperature short-time extrusion cooking of wheat-starch and flour .1. effect of moisture and flour type on extrudate properties. Cereal Chemistry, 59(6), 529-533.
Faubion, J. M. \& Hoseney, R. C. (1982-b). Hightemperature short-time extrusion cooking of wheat-starch and flour .2. effect of protein and lipid on extrudate properties. $\mathrm{Ce}$ real Chemistry, 59(6), 533-537.

Fletcher, S., Richmond, P., \& Smith, A. (1985). An experimental study of twinscrew extrusion-cooking of maize grits. Journal of Food Engineering, 4(4), 291312. doi:10.1016/0260-8774(85)90009-3

Fukui, K., Aoyama, T., Hashimoto, Y., \& Yamamoto, T. (1993). Effect of extrusion of soy protein isolate on plasma cholesterol level and nutritive value of protein in growing male rat. Nippon Eiyo Shokuryo Gakkaishi, 46(3), 211-216. doi:10.4327/ jsnfs.46.211

Gomez, M. H. \& Aguilera, J. M. (1983). Changes in the starch fraction during extrusioncooking of corn. Journal of Food Science, 48(2), 378-381. doi:10.1111/j.1365-2621. 1983.tb10747.x

Gomez, M. H. \& Aguilera, J. M. (1984). A physicochemical model for extrusion of corn starch. Journal of Food Science, 49(1), 40-\&. doi:10.1111/j. 1365-2621. 1984.tb13664.x

Guzmantello, R. \& Cheftel, J. C. (1987). Thiamine destruction during extrusion cooking as an indicator of the intensity of thermal-processing. International Journal of Food Science and Technology, 22(5), 549-562.

Guzmantello, R. \& Cheftel, J. C. (1990). Color loss during extrusion cooking of betacarotene wheat-flour mixes as an indicator of the intensity of thermal and oxidative processing. International Journal of Food Science and Technology, 25(4), 420-434.

Harper, J. M. \& Jansen, G. R. (1981). Nutritional food products by low cost technology. Summary Report, Colorado State University. Retrieved from http://pdf.usaid. gov/pdf_docs/PNAAL120.pdf

Harper, J. M. \& Clark, J. P. (1979). Food extrusion. Critical Reviews in Food Science and Nutrition, 11 (2), 155-215.

Hernandez-Diaz, J. R., Quintero-Ramos, A., Barnard, J., \& Balandran-Quintana, R. R. (2007). Functional properties of extru- 
dates prepared with blends of wheat Flour/Pinto bean meal with added wheat bran. Food Science and Technology International, 13(4), 301-308. doi:10 . 1177/ 1082013207082463

Ilo, S., Liu, Y., \& Berghofer, E. (1999). Extrusion cooking of rice flour and amaranth blends. Food Science and Technology-lebensmittelwissenschaft \& Technologie, 32(2), 79-88.

Kadan, R. S., Bryant, R. J., \& Pepperman, A. B. (2003). Functional properties of extruded rice flours. Journal of Food Science, 68(5), 1669-1672.

Kaletunc, G. \& Breslauer, K. J. (1993). Glass transitions of extrudates - relationship with processing-induced fragmentation and end-product attributes. Cereal Chemistry, $70(5), 548-552$.

Kannadhason, S., Muthukumarappan, K., \& Rosentrater, K. A. (2009). Effects of ingredients and extrusion parameters on aquafeeds containing ddgs and tapioca starch. Journal of Aquaculture Feed Science and Nutrition, 1(1), 6-21.

Kirby, A., Ollett, A.-L., Parker, R., \& Smith, A. (1988). An experimental study of screw configuration effects in the twin-screw extrusion-cooking of maize grits. Journal of Food Engineering, 8(4), 247-272. doi:10. 1016/0260-8774(88)90016-7

Kothakota, A., Jindal, N., \& Thimmaiah, B. (2013). A study on evaluation and characterization of extruded product by using various by-products. African Journal of Food Science, 7(12), 485-497. doi:10.5897/ AJFS2013.1065

Launay, B. \& Lisch, J. M. (1983). Twin-screw extrusion cooking of starches: flow behaviour of starch pastes, expansion and mechanical properties of extrudates. Journal of Food Engineering, 2(4), 259-280.

Lawton, J. W., Davis, A. B., \& Behnke, K. C. (1985). High-temperature, short-time extrusion of wheat gluten and a bran-like fraction. Cereal Chemistry, 62(4), 267-271.

Lazou, A. \& Krokida, M. (2010). Structural and textural characterization of corn-lentil extruded snacks. Journal of Food Engineering, 100(3), 392-408. doi:10.1016/j . jfoodeng.2010.04.024
Lin, S., Huff, H., \& Hsieh, F. (2000). Texture and chemical characteristics of soy protein meat analog extruded at high moisture. Journal of Food Science, 65(2), 264-269. doi:10 . 1111/j.1365-2621.2000.tb15991.x

Maga, J. A. \& Sizer, C. E. (1978). Ascorbic acid and thiamin retention during extrusion of potato flakes. LWT Lebensmitt Wissensch Technologie, 11 (4), 192-194.

Mahungu, S. M., Diaz-Mercado, S., Li, J., Schwenk, M., Singletary, K., \& Faller, J. (1999). Stability of isoflavones during extrusion processing of corn/soy mixture. Journal of Agricultural and Food Chemistry, 47(1), 279-284. doi:10.1021/ jf980441q

Maurice, T. \& Stanley, D. (1978). Texturestructure relationships in texturized soy protein iv. influence of process variables on extrusion texturization. Canadian Institute of Food Science and Technology Journal, 11(1), 1-6. doi:10.1016 / S0315-5463(78) 73151-2

Mercier, C. (1979). Structure and digestibility alterations of cereal starches by twin- screw extrusion - cooking. (Vol. 1, pp. 795-807). London: Applied Science Publisher Ltd.

Mercier, C. (1980). Formation of amylose-lipid complexes by twin-screw extrusion cooking of manioc starch. Cereal Chemistry, 57, 49.

Mercier, C. \& Feillet, P. (1975). Modification of carbohydrate components by extrusioncooking of cereal products. Cereal Chemistry, 52(3), 283-297.

Mercier, C., Linko, P., \& Harper, J. M. (1989). Extrusion cooking. American Assoc. Cereal Chemists, St. Paul. Minnesota.

Mezreb, K., Goullieux, A., Ralainirina, R., \& Queneudec, M. (2003). Application of image analysis to measure screw speed influence on physical properties of corn and wheat extrudates. Journal of Food Engineering, 57(2), 145-152. doi:10.1016/ S0260-8774(02)00292-3

Mitrus, M. (2005). Changes of specific mechanical energy during extrusion cooking of thermoplastic starch. TEKA Kom. Mot. Energ. Roln, 5, 152-157. 
Extrusion cooking technology: principle mechanism and effects $\mid 127$

Moraru, C. \& Kokini, J. (2003). Nucleation and expansion during extrusion and microwave heating of cereal foods. Comprehensive Reviews in Food Science and Food Safety, 2(4), 147-165. doi:10.1111/j.1541-4337. 2003.tb00020.x

Moscicki, L., Mitrus, M., Wojtowicz, A., Oniszczuk, T., \& Rejak, A. (2013). Advances in agrophysical research, intech. ExtrusionCooking of Starch. In Prof. Stanisław Grundas. doi: $10.5772 / 52323$

Navale, S. A., Swami, S. B., \& Thakor, N. J. (2015). Extrusion cooking technology for foods: a review. Journal of Ready to Eat Food, 2(3), 66-80.

Oke, M. O., Awonorin, S. O., \& Workneh, T. S. (2013). Expansion ratio of extruded water yam (dioscorea alata) starches using a single screw extruder. African Journal of Agricultural Research, 8(9), 750-762. doi:10.5897/AJAR12.1091

Onwulata, C., Smith, P., Konstance, R., \& Holsinger, V. (2001). Incorporation of whey products in extruded corn, potato or rice snacks. Food Research International, 34(8), 679-687. doi:10 . 1016 / S0963 - 9969(01) 00088-6

Ozer, E. A., Herken, E. N., Guzel, S., Ainsworth, P., \& Ibanoglu, S. (2006). Effect of extrusion process on the antioxidant activity and total phenolics in a nutritious snack food. International Journal of Food Science and Technology, 41(3), 289-293. doi:10.1111/j. 1365-2621.2005.01062.x

Pardeshi, I. L. \& Chattopadhyay, P. K. (2014). Whirling bed hot air puffing kinetics of rice-soy ready-to-eat (rte) snacks. Journal of Ready to Eat Food, 1(1), 01-10.

Pathania, S., Singh, B., Sharma, S., Sharma, V., \& Singla, S. (2013). Optimization of extrusion processing conditions for preparation of an instant grain base for use in weaning foods. International Journal of Engineering Research and Applications, 3(3), 10401049.

Pawar, S. G., Pardeshi, I. L., Borkar, P. A., \& Rajput, M. R. (2014). Optimization of process parameters of microwave puffed sorghum based ready-to-eat (RTE) food. Journal of Ready to Eat Food, 1(2), 59-68.
Pham, C. B. \& Del Rosario, R. R. (1986). Studies on the development of texturized vegetable products by the extrusion process. International Journal of Food Science and Technology, 21(5), 569-576.

Phillips, R. D. \& Falcone, R. G. (1988). Extrusion of sorghum and sorghum peanut mixtures - effect of barrel temperature and feed moisture on physical-textural characteristics. Journal of Texture Studies, 19(2), 185-197. doi:10.1111/j.1745- 4603.1988. tb00935.x

Politz, M. L., Timpa, J. D., \& Wasserman, B. P. (1994). Quantitative measurement of extrusion-induced starch fragmentation products in maize flour using nonaqueous automated gel-permeation chromatography. Cereal Chemistry, 71(6), 532-536.

Sebio, L. \& Chang, Y. (2000). Effects of selected process parameters in extrusion of yam flour (Dioscorea rotundata) on physicochemical properties of the extrudates. Nahrung-food, 44 (2), 96-101. doi:10.1002/ (SICI) 1521-3803(20000301) 44:2 $\langle 96::$ AIDFOOD96>3.0.CO;2-9

Seib, P. A. (1976). An introduction to food extrusion. Kansas State University Dept. of Grain Sci. Manhattan, KS p, 1.

Shukla, C., Muthukumarappan, K., \& Julson, J. (2005). Effect of single-screw extruder die temperature, amount of distillers' dried grains with solubles (DDGS), and initial moisture content on extrudates. Cereal Chemistry, 82 (1), 34-37. doi:10.1094/CC82-0034

Singh, B., Sekhon, K. S., \& Singh, N. (2007). Effects of moisture, temperature and level of pea grits on extrusion behaviour and product characteristics of rice. Food Chemistry, 100(1), 198-202. doi:10.1016/j.foodchem. 2005.09.042

Smith, A. C. (1992). Studies on the physical structure of starch-based materials in the extrusion cooking process. Food Extrusion Science and Technology, 36, 573-618.

Sriburi, P. \& Hill, S. E. (2000). Extrusion of cassava starch with either variations in ascorbic acid concentration or ph. International Journal of Food Science and Technology, 
35(2), 141-154. doi:10.1046/j.1365-2621. 2000.00360.x

Ummadi, P., Chenoweth, W. L., \& Uebersax, M. A. (1995). The influence of extrusion processing on iron dialyzability, phytates and tannins in legumes. Journal of Food Processing and Preservation, 19(2), 119131. doi:10. $1111 / \mathrm{j} .1745-4549.1995$. tb00282.x

van Lengerich, B. (1990). Influence of extrusion processing on in-line rheological behavior, structure, and function of wheat starch. In Dough rheology and baked product texture (pp. 421-471). Springer.

van Zuilichem, D., van Roekel, G., Stolp, W., \& van't Riet, K. (1990). Modelling of the enzymatic conversion of cracked corn by twinscrew extrusion cooking. Journal of Food Engineering, 12(1), 13-28. doi:10.1016/ 0260-8774(90)90016-2

Wen, L. F., Rodis, P., \& Wasserman, B. P. (1990). Starch fragmentation and protein insolubilization during twin-screw extrusion of corn meal. Cereal Chemistry, 67(3), $268-275$. 